thermometer use would be much greater, resulting in a cost savings of $\$ 220,851$ to $\$ 856,851$ over a 3-year period, even at the rates of infection observed in this study.

The infection control benefits of disposable thermometers demonstrated in this study may be achievable by other less expensive measures. More rigid disinfection practices, such as sponging the electronic thermometers with disinfectant for removal of $C$ difficile, may decrease the rate of nosocomial $C$ difficile infection, but no data are available regarding the effectiveness of such measures. Other less expensive forms of thermometers, such as individualized glass thermometers, might be expected to provide the same protection from cross-infection as single-use, disposable thermometers; but, these also have associated disadvantages, such as potential trauma from broken glass, mercury poisoning, ${ }^{14}$ and increased nursing-time requirements. Further study is needed to define best how to minimize the role of thermometers as vectors in the transmission of nosocomial $C$ difficile infections in a practical and cost-effective manner.

\section{REFERENCES}

1. Brooks SE, Veal RO, Kramer M, Dore L, Schupf N, Adachi M. Reduction in the incidence of Clostridium difficile-associated diarrhea in an acute care hospital and a skilled nursing facility following replacement of electronic thermometers with single-use disposables. Infect Control Hosp Epidemiol 1992;13:98-103.
2. Smith L, Prince HN, Johnson E. Bacteriologic studies on electronic hospital thermometers. Infect Control 1981;2:315-316.

3. Brooks S, Veal R, Kramer M, Adachi M. Clostridium difficile-associated diarrhea. Infect Control Hosp Epidemiol 1990;11:574.

4. McAllister TA, Roud JA, Marshall A, Holland BM, Turner TL. Outbreak of Salmonella eimsbuettel in newborn infants spread by rectal thermometers. Lancet 1986;1262-1264.

5. Livornese LL, Dias S, Samel C, Romanowski B, Taylor S, May T, et al. Hospital-acquired infection with vancomycin-resistant Enterococcus faecium transmitted by electronic thermometers. Ann Intern Med 1992;117:112-116.

6. Scleupner MA, Garner DC, Sosnowski KM, Schleupner CJ, Barrett LJ, Silva E, et al. Concurrence of Clostridium difficile toxin A enzyme-linked immunosorbent assay, fecal lactoferrin assay, and clinical criteria with $C$ difficile cytotoxin titer in two patient cohorts. J Clin Microbiol 1995;33:1755-1759.

7. Garner JS, Jarvis WR, Emori TG, Horan TC, Hughes JM. CDC definitions for nosocomial infections. Am J Infect Control 1988;16:128-140.

8. Wenzel RP, Osterman CA, Hunting KJ, Gwaltney JM, Jr. Hospital acquired infections, I: surveillance in a university hospital. Am J Epidemiol 1976:103:251-260.

9. Horan TC, Gaynes RP, Martone WJ, Jarvis WR, Emori TG. CDC definitions of nosocomial surgical site infections, 1992: a modification of CDC definitions of surgical wound infections. Infect Control Hosp Epidemiol 1992;13:606-608

10. Documenta Geigy: Scientific Tables. Basle, Switzerland: JR Geigy; 1970:85

11. Meinert CL. Clinical Trials: Design, Conduct and Analysis. New York, NY: Oxford University Press; 1986:83

12. Kofsky P, Rosen L, Reed J, Tolmie M, Ufberg D. Clostridium difficile-a common and costly diagnosis. Dis Colon Rectum 1991;34:244-248.

13. Wilcox MH, Cunniffe JG, Trundle C, Redpath $\mathrm{C}$. The costs associated with nosocomial Clostridium difficile infection. In: Abstracts of the 36th Interscience Conference on Antimicrobial Agents and Chemotherapy; September 15-18, 1996; New Orleans, LA. American Society of Microbiology; 1996:295. Abstract N16.

14. Blumenthal I. Which thermometer? Lancet 1991;337:1483.

\title{
HIV-Related Laws
}

\section{Gina Pugliese, RN, MS Martin S. Favero, PhD}

The AIDS Litigation Project has reviewed nearly 600 reported cases involving individuals with HIV infection and AIDS in the federal and state courts in the United States between 1991 and 1997. Cases were identified through a federal and 50-state computer and library search. An important subset of litigation relates to HIV and AIDS in the public health and healthcare systems, because the law affects healthcare institutions and professionals, patients, and public health policy in
America. This subset of HIV and AIDS litigation includes testing and reporting; privacy, the duty to warn, and the right to know; physician standards of care in prevention and treatment; and discrimination and access to health care.

A review of these laws demonstrates a reliance on voluntary testing and protection of patient privacy through HIV-specific statutes and the common law. Negligence with potential civil and criminal liability has been alleged in cases of erroneous or missed diagnosis of HIV infection. In the first AIDS case to be considered by the Supreme Court, the court will decide whether patients with asymptomatic HIV infection are protected under the Americans With Disabilities Act.

The authors conclude that considerable progress has been made, both socially and legally, during the first 2 decades of the epidemic, but much still needs to be accomplished to protect privacy, prevent discrimination, and promote tolerance.

FROM: Gostin LO, Webber DW. HIV Infection and AIDS in the public health and health care systems: the role of law and litigation. JAMA 1998;279:1108-1113. 